\title{
ŻYCIE I DZIAŁALNOŚĆ NAUKOWA KS. PROF. DRA HAB. FRANCISZKA DRĄCZKOWSKIEGO ${ }^{1}$
}

1. Człowiek i kapłan. Ksiądz Franciszek Drączkowski urodził się 26 kwietnia 1941 roku w Fordonie (obecnie dzielnica Bydgoszczy) jako trzecie z pięciorga dzieci Józefa Drączkowskiego i Zofii z domu Witkowskiej. O rodzicach tak pisał Ksiądz Profesor w swojej Autobiografii, opublikowanej w 2010 roku:

„Moi rodzice, Zofia i Józef, byli szczęśliwym małżeństwem. Dopełniali się charakterami. Ojciec, niepoprawny optymista, był rozmowny i poza pracą niczym się zbytnio nie przejmował. Matka przeciwnie, milcząca i małomówna, poważnie podchodziła do wszystkich spraw życiowych"2.

Oprócz Franciszka, państwo Drączkowscy mieli jedną - najstarszą - córkę Jadwigę, oraz synów: starszego Jana i młodszych Edmunda i Andrzeja.

Okres wojny oraz pierwszych lat powojennych, w których przyszło wzrastać małemu Franciszkowi, nie dawał znacznych możliwości do nauki i edukacji. Wprawdzie podczas niemieckiej okupacji urządzono w fordońskiej plebanii przedszkole, ale trzyletni wówczas Franciszek nie znosił dobrze rozstania $\mathrm{z}$ domem $\mathrm{i}$ - jak sam stwierdził po latach - wraz z kolegą Heniem, wylewał gorzkie łzy rozłąki siedząc cały dzień przed plebanią? Dopiero zakończenie wojny pozwoliło uruchomić prowadzone przez Siostry Szarytki przedszkole - ochronkę - z prawdziwego zdarzenia. Uczęszczające tam dzieci, w tym dwóch braci Drączkowskich - Edmund i Franciszek oprócz zabawy, zdobywały także podstawy wiedzy religijnej, uczyły się modlitw i śpiewu pobożnych pieśni. W tej dziedzinie, która w przyszłości miała stać się przewodnią w życiu Księdza Profesora, duży wpływ miał także dom rodzinny, a szczególnie mama Zofia, babcia Joanna i siostra Jadwiga, która zaszczepiła w młodszym bracie m.in. zamiłowanie do rorat i codziennego uczestnictwa we Mszy św.

\footnotetext{
${ }^{1}$ Niniejszy biogram ks. prof. dra hab. Franciszka Drączkowskiego jest zmienioną i uzupełnioną wersją biogramu zamieszczonego w księdze jubileuszowej dedykowanej Księdzu Profesora. Por. M. Wysocki, Dies annorum nostrorum sunt septuaginta anni... (Ps 90,10). Życie i działalność naukowa ks. prof. Franciszka Drączkowskiego, w: Fructus Spiritus est Caritas. Księga Jubileuszowa ofiarowana Księdzu Profesorowi Franciszkowi Draczkowskiemu z okazji siedemdziesiatej rocznicy urodzin, czterdziestopięciolecia święceń kapłańskich i trzydziestopięciolecia pracy naukowej, red. M. Wysocki, Lublin 2011, 29-39.

${ }^{2}$ F. Drączkowski, Będę na wieki stawit taski Pana. Autobiografia, Pelplin 2010, 8-9.

${ }^{3}$ Por. tamże, s. 15.
} 
W roku 1948, jako siedmioletni chłopiec, Franciszek rozpoczął naukę w szkole podstawowej. Tam też miał szczęście spotkać wyjątkowych pedagogów, którzy byli nie tylko przekazicielami wiedzy, ale przede wszystkim autorytetami i wzorcami. Dzięki ich pracy, ale także wiedzy wyniesionej z domu, uczeń Franciszek Drączkowski nie miał najmniejszych problemów z nauką, o czym świadczyły najwyższe noty na świadectwach oraz zamiłowanie do literatury, którą już wówczas ,pochłaniał” w ogromnej ilości.

Ten sielski okres został gwałtownie przerwany, jak wspomina, $\mathrm{z}$ chwilą śmierci stryja Franciszka, brata ojca, w roku 1954. Rodzina postanowiła bowiem, że to właśnie ojciec Księdza Profesora przejmie ojcowiznę, na której do tej pory gospodarzył wuj Franciszek. Wiązało się to z przeprowadzką, ale przede wszystkim z nowymi zajęciami dla czterech braci Drączkowskich. Tę zmianę tak wspomina:

„Prace w gospodarstwie były czasochłonne. Wówczas nie było, jak dziś, nowoczesnych maszyn rolniczych. Ziemię orało się pługiem jednoskibowym. Żyto koszono ręcznie - kosami. Tak samo ziemniaki - kopano ręcznie. Ojciec, jako inwalida, nie mógł się włączyć do prac gospodarskich. Większość tych zajęć spadała na barki jego synów. [...] Skończyły się dawne dobre czasy. Zaczęła się ciężka praca w polu i w domu. Miałem wówczas dopiero 13 lat i byłem w szóstej klasie szkoły podstawowej”"

Po ukończeniu szkoły podstawowej, od lipca 1955 do sierpnia 1956 r., nastoletni Franciszek przerwał dalszą edukację, aby pomagać ojcu w prowadzeniu gospodarstwa. Dopiero ukończenie szkoły podstawowej przez brata Edmunda i zdecydowana postawa Matki pozwoliły księdzu Drączkowskiemu rozpocząć z dniem 1 września 1956 r. naukę w szóstym liceum ogólnokształcącym im. J.J. Śniadeckich w Bydgoszczy.

Okres licealny to, jak stwierdził w swych wspomnieniach Ksiądz Profesor, „dni i tygodnie, ujęte $\mathrm{w}$ ramy regularnego życia przepełnionego nauką, pracą i modlitwą"s. Codzienne dojazdy pociągiem z Fordonu do Bydgoszczy, godziny spędzone w bibliotece, gdzie licealista Franciszek Drączkowski pracował jako ochotnik, oraz zajęcia $\mathrm{z}$ doskonałymi pedagogami zaowocowały zdobytą wiedzą, a nade wszystko znajomością języka łacińskiego. Już wówczas późniejszy ks. Franciszek czuł, że jego powołaniem jest służba Bogu i ludziom. I choć skrywał swoje plany, co w komunistycznej rzeczywistości było smutną koniecznością, wiele osób to przeczuwało, a on sam nie ukrywał swojej wiary i stawał niejednokrotnie w obronie swoich przekonań, co mogło przynieść represje ze strony władz. Ujawnienie zamierzeń co do przyszłości możliwe było dopiero po zdaniu egzaminu maturalnego, co nastąpiło w maju $1960 \mathrm{r}$. Abiturient Franciszek Drączkowski zdał maturę z wynikiem bardzo dobrym z czterech przedmiotów: języka polskiego, matematyki, historii i języka łaciń-

\footnotetext{
${ }^{4}$ Tamże, s. 21.

${ }^{5}$ Tamże, s. 25.
} 
skiego. Po otrzymaniu świadectwa maturalnego i po balu maturalnym mógł już bez przeszkód powiedzieć: „zamierzam pójść do Wyższego Seminarium Duchownego w Pelplinie"6.

Kolejny więc etap życia Księdza Profesora Drączkowskiego zaczął się $\mathrm{z}$ chwilą przestąpienia progów seminarium duchownego w Pelplinie w roku 1960. Po pięćdziesięciu latach od tego momentu w swej Autobiografii Ksiądz Profesor ten moment tak określił:

„Po latach ciężkiej pracy fizycznej w gospodarstwie rolnym oraz wytrwałych zmaganiach związanych z walką o prawo do nauki, przejście do życia seminaryjnego było wkroczeniem do upragnionej krainy szczęśliwości. Z tej racji zapewne, te lata studiów w Pelplinie, z powodu niebywałego kontrastu w stosunku do poprzednich lat, określiłem jako «Najpiękniejszą przygodę mego życia»" "

Okres seminarium był czasem, w pewnym sensie ,spokoju i ładu” po niełatwym okresie liceum, ale przede wszystkim były to „lata wypełnione nauką, modlitwą, lekturą dobrych książek, śpiewem liturgicznym oraz nabożeństwami w kaplicy seminaryjnej i w katedrze"8. Spośród profesorów Almae Matris Pelplinensis do dnia dzisiejszego Ksiądz Drączkowski szczególnie wspomina rektora - ks. Antoniego Liedtkego, który wykładał historię Kościoła, ks. infułata Jerzego Buxakowskiego, wicerektora - ks. Edwarda Zawiszewskiego, ks. kanonika Szymona Dreszlera oraz ks. dr. Edmunda Piszcza, który ,imponował szaloną erudycją i oczytaniem; jego wykłady o reformacji były «koncertowe»" Nie trudno więc zrozumieć skąd wypływa umiłowanie zgłębiania dziejów Kościoła u Księdza Profesora, które znalazło odzwierciedlenie w wyborze tematu pracy magisterskiej. Na piątym roku studiów kleryk Drączkowski nawiązał bowiem kontakt z ojcem Janem Marią Szymusiakiem SJ, wykładowcą patrologii na Katolickim Uniwersytecie Lubelskim, który zaproponował jako temat pracy: Zagadnienie postów w ,Mowach” Leona Wielkiego.

29 maja 1966 r. w katedrze pelplińskiej ks. Franciszek Drączkowski przyjął święcenia kapłańskie z rąk ks. bp. Kazimierza Józefa Kowalskiego. Swą Mszę św. prymicyjną odprawił 5 czerwca w kościele św. Mikołaja w Fordonie. Kaznodzieją prymicyjnym był ks. prof. Jerzy Buxakowski. Zgodnie z biskupim dekretem neoprezbiter Drączkowski został skierowany do pracy jako wikariusz w parafii św. Mikołaja w Parchowie na Kaszubach, gdzie spędził dwa lata. To tam w długie zimowe wieczory pracował nad tekstem pracy magisterskiej poprawianej przez o. dr. Szymusiaka, tam - szczególnie podczas kolędy - doświadczał kaszubskiej gościnności, tam też wykrystalizowało się pragnienie studiowania Ojców Kościoła, które spełniło się w roku 1968,

\footnotetext{
6 Tamże, s. 29.

7 Tamże, s. 32.

${ }^{8}$ Tamże, s. 39.

9 Tamże, s. 41.
} 
$\mathrm{z}$ chwilą opuszczenia wikariatu w celu podjęcia studiów specjalistycznych najpierw z patrologii, a następnie również z filologii klasycznej w Katolickim Uniwersytecie Lubelskim.

Posługa kapłańska ks. prof. Franciszka Drączkowskiego nie skończyła się jednak z chwilą odejścia $\mathrm{z}$ wikariatu. W dalszym ciągu służył on swoją kapłańską posługą czy to podczas wakacyjnych wyjazdów zagranicznych, czy to w Lublinie posługując wspólnotom neokatechumenalnym, ale także prowadząc liczne rekolekcje i służąc pomocą w rodzinnym Fordonie i innych parafiach. Swoim kapłaństwem dzielił się także z rodziną i przyjaciółmi błogosławiąc małżeństwa, udzielając chrztu, głosząc prymicyjne kazania.

W roku 1998 ks. prof. Drączkowski, zachęcony przez księdza biskupa Wacława Świerzawskiego z Sandomierza, przystąpił do powołanej przez niego w tym samym roku Wspólnoty Kapłanów Chrystusa Paschalnego, która spotykając się kilka razy do roku, wspólnie się modli, celebruje Eucharystię, słucha biskupiej konferencji ascetycznej i dzieli się swoimi przemyśleniami, aby budować swoje kapłaństwo.

2. Naukowiec. Jak wspomniano powyżej, już w czasie studiów w Wyższym Seminarium Duchownym w Pelplinie ks. prof. Drączkowski zainteresował się pismami Ojców Kościoła. Nawiązanie korespondencji z o. Janem Szymusiakiem zaowocowało opracowaniem tematu Zagadnienie postów w ,Mowach" Leona Wielkiego. Pierwsza redakcja tej pracy została zakończona w marcu 1966 r. W roku 1968 z polecenia biskupa chełmińskiego ks. Franciszek został skierowany na studia specjalistyczne z patrologii w Instytucie Historii Kościoła KUL w Lublinie. Mając świadomość, że studium Ojców Kościoła nie jest możliwe bez gruntownej znajomości języków klasycznych, do których przejawiał szczególne zainteresowanie, w roku 1969 Ksiądz Profesor podjął równolegle regularne studia z filologii klasycznej na Wydziale Nauk Humanistycznych KUL. Wkrótce - w czerwcu 1970 r. - uzyskał licencjat i stopień magistra teologii w zakresie historii Kościoła na podstawie pracy, rozpoczętej jeszcze w czasach seminaryjnych, pod kierunkiem o. Szymusiaka. 14 września 1973 r. ks. Drączkowski uzyskał stopień magistra filologii klasycznej (z wyróżnieniem) na podstawie pracy: Struktury semantyczne wyrazu paideia $w$,Stromateis" Klemensa Aleksandryjskiego, napisanej pod kierunkiem prof. Janiny Niemirskiej-Pliszczyńskiej, zaś 23 listopada tegoż roku obronił pracę doktorską z patrologii: Formy i zasady pierwszych wspólnot chrześcijańskich na podstawie „Stromatów” Klemensa Aleksandryjskiego, której promotorem był ks. prof. Bolesław Kumor.

Bezpośrednim powodem tak szybkiego sfinalizowania studiów w KUL była propozycja prof. Janiny Pliszczyńskiej dotycząca kontynuowania studiów na Uniwersytecie Salezjańskim w Rzymie, na które Ksiądz Profesor został skierowany w sposób oficjalny przez księdza biskupa Bernarda Czaplińskiego, ordynariusza chełmińskiego. Od listopada 1973 do września 
1976 r. ks. Drączkowski studiował w Institutum Altioris Latinitatis. Okres ten był nie tylko czasem pracy intelektualnej - oprócz podjętych studiów także wakacyjnej nauki języka francuskiego w Paryżu - ale również czasem okresowej pracy duszpasterskiej, poprzez pomoc w parafiach w Niemczech i we Włoszech, czy też głoszone co miesiąc w Radiu Watykańskim homilie $^{10}$. W czerwcu 1975 r. ks. Franciszek Drączkowski uzyskał licencjat ex litteris classicis et christianis na podstawie pracy De nonnullis praecipuis proclivitatibus antiquarum sectarum heterodoxarum secundum ,, Stromateis" Clementis Alexandrini, napisanej pod kierunkiem prof. Calogero Riggi. We wrześniu 1976 r. zdobył stopień doktora ex litteris classicis et christianis na podstawie rozprawy: Qua paideia Clemens Alexandrinus imbutus appareat in animadvertenda falsa gnosi, która uzyskała maksymalną ocenę: 30 punktów na 30 możliwych. Po powrocie do kraju 1 października roku 1976 podjął pracę w Międzywydziałowym Zakładzie Leksykograficznym KUL, najpierw jako dokumentalista, a od 1978 na stanowisku adiunkta. Pierwszym tomem w opracowaniu którego brał udział ks. prof. Franciszek był tom trzeci Encyklopedii Katolickiej, w którym znalazło się 12 haseł przez niego opracowanych. W roku 1980 został mianowany redaktorem działu teologii patrystycznej i patrologii Encyklopedii. Będąc zatrudnionym w redakcji encyklopedii rozpoczął prace nad rozprawą habilitacyjną, które zostały uwieńczone kolokwium habilitacyjnym na podstawie rozprawy Kościót - Agape wedtug Klemensa Aleksandryjskiego ${ }^{11}$ w dniu 9 grudnia 1980. Przed habilitacją Ksiądz Profesor opublikował w sumie 26 prac (artykuły naukowe i hasła encyklopedyczne) z zakresu historii starożytnej, religioznawstwa, patrologii, patrystyki, teologii moralnej, herezjologii oraz pedagogiki patrystycznej. Przedmiotem badań szczegółowych stała się agapetologia i eklezjologia Klemensa Aleksandryjskiego. Zgodnie z obowiązującym wówczas prawem oficjalnie stopień naukowy doktora habilitowanego został zatwierdzony przez Ministra Nauki, Szkolnictwa Wyższego i Techniki w dniu 5 listopada 1982 r. i od tego dnia mógł go Ksiądz Profesor używać. W dwa lata później, 18 września 1984 r., ksiądz Drączkowski został powołany na stanowisko docenta na Wydziale Teologii KUL oraz otrzymał nominację na kierownika Katedry Patrologii. 27 stycznia 1992 r. ks. Drączkowski został zatrudniony na stanowisku profesora nadzwyczajnego KUL. Kolejnym etapem na naukowej drodze ks. prof. Franciszka był tytuł naukowy profesora nauk teologicznych, który otrzymał w marcu 1992 r. po wypromowaniu dwóch doktorów: ks. Józefa Grzywaczewskiego i ks. Jerzego Pałuckiego oraz przedstawieniu pracy naukowej Miłość synteza chrześcijaństwa ${ }^{12} .17$ maja 1997 r. został zatrudniony na stanowisku profesora zwyczajnego w Katedrze Patrologii Greckiej KUL. Owocem 38 lat pracy naukowej ks. prof. Franciszka Drącz-

\footnotetext{
${ }^{10}$ Zob. tenże, Do Boga, który uwesela, Lublin 1994.

${ }^{11}$ Lublin 1983.

${ }^{12}$ Lublin $1990^{1}, 1991^{2}$ (poszerzone).
} 
kowskiego jest opublikowanie 32 pozycji książkowych własnego autorstwa, 7 opracowań redakcyjnych i współredakcyjnych, 66 artykułów naukowych zarówno w języku polskim, jak i w językach obcych oraz 98 haseł encyklopedycznych publikowanych przede wszystkim w Encyklopedii Katolickiej, z którą ks. Drączkowski rozpoczynał swoją naukową drogę. Z pewnością ukoronowaniem działalności naukowej - ale także dydaktycznej - Księdza Profesora jest podręcznik patrologii ${ }^{13}$. Efektem studiów i zainteresowań naukowo-duszpasterskich Księdza Profesora jest także stworzona przez niego metoda wykresograficzna w teologii, której ks. Franciszek poświęcił wiele pozycji książkowych ${ }^{14}$. Rdzeniem i osią metody, jest historia zbawienia przedstawiona $\mathrm{w}$ wykresach geometrycznych ${ }^{15}$, obrazująca następujące prawdy wiary: Bóg Odwieczny, Trójca Święta, stworzenie aniołów, upadek aniołów, raj - przyjaźń człowieka z Bogiem, grzech pierworodny, obietnica zbawienia, wcielenie Syna Bożego, misterium odkupienia, Kościół Chrystusowy, Kościół - Świątynią Ducha Świętego, Chrzest, miłość Boża, miłość bliźniego, droga doskonalenia, czyściec, chrzest pragnienia, świętych obcowanie, piekło - odłączenie od Boga, miłość doskonałą antycypacją nieba. Metoda doczekała się wielu recenzji, których autorami są m.in.: ks. prof. Wojciech Cichosz, o. prof. Bazyli R. Degórski (trzy recenzje), ks. bp prof. Andrzej F. Dziuba, ks. prof. Augustyn Eckmann, prof. Manfred Hauke, prof. Luciana M. Mirri, o. prof. Antoni J. Nowak (dwie recenzje), ks. dr Piotr Paciorek, ks. prof. Roman B. Sieroń, prof. Helena. Słotwińska (dwie recenzje), ks. dr hab. Waldemar Turek (dwie recenzje), o. dr Krzysztof Wendlik, ks. prof. Ireneusz Werbiński (dwie recenzje), oraz ks. dr Dariusz Żurański ${ }^{16}$.

Do naukowych osiągnięć ks. prof. Drączkowskiego zaliczyć trzeba z pewnością również liczne recenzje dorobku i prac naukowych. W przeciągu prawie 30 lat jako samodzielny pracownik naukowy Ksiądz Profesor napisał 20 recenzji prac doktorskich, 9 recenzji dorobku w przewodzie habilitacyjnym oraz $13 \mathrm{w}$ sprawie stanowiska lub tytułu profesora.

\footnotetext{
${ }^{13}$ Por. tenże, Patrologia, Pelplin - Lublin 1998, 1999², 2001³, $2009^{4}$

${ }^{14}$ Por. tenże, Miłość synteza chrześcijaństwa, Lublin 1990, 19912; Gott ist die Liebe. Eine patristische Studie, Lublin 1993; Poza miłościa nie ma zbawienia, Pelplin - Torun 1996; Miłość - Agape synteza chrześcijaństwa, Pelplin - Torun 1997; La salvezza e nell' amore, Roma 1998; Nowa wizja teologii. Ujęcie graficzne, Pelplin - Lublin 2000; Metoda wykresograficzna w katechezie, Pelplin 2001; Skrót katechizmu w ujęciu graficznym, Lublin - Sandomierz 2002; Teologia w kategoriach geometryczno-matematycznych, Pelplin 2003; Supernatural Geometry, Lublin 2004; Die Theologie In geometrischer Darstellung, Lublin 2004; Przyjaźń z Bogiem źródłem szczęścia, Pelplin 2004; Poza Kościołem nie ma zbawienia. Ujęcie graficzne, Pelplin 2008; Dogmatyka w obrazach graficznych. Zagadnienia wybrane, Pelplin 2011; Geometryczna struktura teologii, Pelplin 2012; Synteza teologii w ujęciu graficznym, Pelplin 2012; Synthese der Theologie in grafischer Darstellung, Leipzig 2013.

${ }^{15}$ Por. P. Szczur, Wkład Katedry Patrologii Greckiej w historiografię kościelna, w: Rola i miejsce Instytutu Historii Kościoła KUL w historiografii, red. J. Walkusz, Lublin 2010, 29.

${ }^{16}$ Zob. Drączkowski, Będę na wieki stawił taski Pana, s. 12 i 183-184.
} 
3. Nauczyciel. Wykłady z patrologii w Katolickim Uniwersytecie Lubelskim nie były pierwszym zetknięciem się Księdza Profesora z młodzieżą i nauczycielską katedrą. Już podczas dwuletniego wikariatu w Parchowie na Kaszubach ks. Drączkowski prowadził katechizację dzieci z klas II-VIII. W roku 1982 zaczął wykładać patrologię (wykład kursoryczny) w Wyższym Seminarium Duchownym w Lublinie oraz sakramentologię patrystyczną w Wyższym Seminarium Duchownym w Pelplinie. Gdy w 1983 r. ks. Drączkowski został powołany na stanowisko p.o. kierownika Katedry Patrologii, powierzono mu wykłady kursoryczne z patrologii na Wydziale Teologicznym oraz prowadzenie seminarium naukowego.

Seminarium patrystyczne - które oficjalnie zainaugurowano z początkiem roku akademickiego 1983/1984 - wznowiono po 12 latach przerwy, spowodowanej przejściem na emeryturę o. prof. Andrzeja Bobera SJ. Zanim jednak doszło do odnowienia działalności pełnoprawnego seminarium naukowego z patrologii, w roku akademickim 1982/1983, przy Katedrze Patrologii, funkcjonowało proseminarium naukowe, którego pierwsze posiedzenie $\mathrm{w}$ obecności prowadzącego - ks. dr. Franciszka Drączkowskiego - oraz trojga uczestników odbyło się 26 października 1982 roku $^{17}$. Dopiero w następnym roku akademickim nastąpiła zmiana statusu proseminarium, które zostało podniesione do rangi seminarium naukowego, w związku z zatwierdzeniem przez Ministerstwo Nauki, Szkolnictwa Wyższego i Techniki habilitacji ks. dr. Drączkowskiego oraz jego zatrudnieniem na pełnym etacie na Wydziale Teologii KUL na stanowisku docenta. Od tej chwili zaczęło działać seminarium naukowe z patrologii, które w kolejnych latach istnienia notowało tendencje wzrostowe ilości uczestników (w 1983 - 13 uczestników, w 1991 - 64 uczestników) ${ }^{18}$. Posiedzenia seminarium patrystycznego odbywały się według ustalonego porządku: otwierała je modlitwa, następnie był odczytywany i omawiany protokół z poprzedniego posiedzenia, potem sprawdzana była lista obecności, następowały ogłoszenia i komunikaty dotyczące życia patrystycznego w Polsce (sympozja, wydawnictwa); zasadniczą częścią seminarium była analiza tekstów patrystycznych oraz dyskusja nad roboczymi planami przygotowywanych prac i nad przedstawionymi fragmentami aktualnie pisanych prac ${ }^{19}$. Owocem pracy seminarium patrystycznego, prowadzonego najpierw przy Katedrze Patrologii, a od roku 1996, przy Katedrze Patrologii Greckiej, jest 13 obronionych doktoratów oraz liczne prace magisterskie i licencjackie. Nie tylko liczby świadczą o dydaktycznym zaangażowaniu Księdza Profesora, ale przede wszystkim uczniowie, którzy słuchali wkładów lub pisali prace pod jego kierunkiem, a jest wśród nich cała plejada znakomitości: ks. abp Mieczysław Mokrzycki, obecnie arcybiskup metropolita lwowski; ks. abp Zbigniew

${ }^{17}$ Por. tenże, Profil organizacyjno-naukowy seminarium patrystycznego w KUL (1983-1993), w: Tysiąc imion Chrystusa, Seminarium Patrystyczne KUL 1983-1993, red. J. Pałucki, Lublin 1994, 29.

${ }_{18}$ Por. tamże, s. 30-33.

19 Tamże, s. 30. 
Stankiewicz, metropolita ryski; ks. bp Mariusz Leszczyński, biskup pomocniczy diecezji zamojsko-lubaczowskiej; ks. bp Adam Szal, biskup pomocniczy diecezji przemyskiej, ks. bp Artur Miziński, biskup pomocniczy archidiecezji lubelskiej i obecnie Sekretarz Generalny Konferencji Episkopatu Polski; ks. prof. dr hab. Jerzy Pałucki, dyrektor Instytutu Historii Kościoła i Patrologii KUL i były dziekan Wydziału Teologii KUL; ks. prof. dr hab. Mariusz Szram, prezes Sekcji Patrystycznej przy Komisji ds. Nauki Katolickiej Konferencji Episkopatu Polski; ks. dr hab. Józef Grzywaczewski, były rektor Polskiego Seminarium Duchownego w Paryżu; ks. dr hab. Dariusz Zagórski, rektor Wyższego Seminarium Duchownego w Toruniu i wielu innych.

Praca dydaktyczna Księdza Profesora nie ograniczała się tylko do Lublina i rodzinnej diecezji pelplińskiej. W roku 1992 ks. Drączkowski podjął również pracę dydaktyczną w Wyższym Seminarium Duchownym w Sandomierzu, gdzie przez kolejne lata prowadził wykłady z patrologii i historii starożytnej.

We wrześniu 1993 r. rozpoczął się kolejny ważny etap w życiu i dydaktycznej działalności ks. prof. Franciszka Drączkowskiego. W powstałej w 1992 r. diecezji toruńskiej zostało erygowane seminarium duchowne, którego rektorstwo biskup Andrzej Suski zaproponował właśnie Księdzu Profesorowi. W swoich wspomnieniach tak pisze o ówczesnych rozterkach:

„Zasadniczy problem był jednak w tym, czy zdołam pogodzić pełnienie obowiązków Rektora WSD w Toruniu i etatowego profesora KUL. W sytuacji analogicznej byli wówczas dwaj moi koledzy: ks. prof. dr hab. Stanisław Kowalczyk, profesor KUL i Rektor WSD w Sandomierzu oraz ks. prof. dr hab. Antoni Tronina, profesor KUL i Rektor WSD w Częstochowie. Postanowiłem skonsultować się z nimi. Zgodnie zapewnili mnie, że takie łączenie funkcji jest możliwe oraz zachęcali mnie, bym nie lękał się podjęcia nowych obowiązków w Toruniu"20.

Profesorskie fiat oficjalnie zostało potwierdzone dekretem biskupa toruńskiego z dnia 20 czerwca 1994 r. mianującym ks. Drączkowskiego Rektorem Wyższego Seminarium Duchownego Diecezji Toruńskiej na okres trzech lat. Jak wspomina Ksiądz Profesor był to okres tworzenia od podstaw struktury toruńskiego seminarium - zarówno duchowej, naukowej, jak i gospodarczej, co możliwe było dzięki doskonałej współpracy z innymi moderatorami (wicerektorami: ks. dr. Krzysztofem Lewandowskim i ks. dr. Mirosławem Mrozem oraz ojcem duchownym ks. mgr. lic. Józefem Szamockim i ekonomem seminaryjnym ks. mgr. Wiesławem Pacakiem). Oprócz pełnienia funkcji rektora ks. Drączkowski prowadził w Toruniu również pracę dydaktyczną wykładając patrologię oraz kierując seminarium naukowym z patrologii, ale także kontynuując równolegle działalność naukową - choć ograniczoną - na Katolickim Uniwersytecie Lubelskim oraz w seminarium w Pelpinie. Natłok zajęć i obo-

${ }^{20}$ Tenże, Będę na wieki stawit taski Pana, s. 137-138. Por. tenże, Z kart historii seminarium toruńskiego. Relacja pierwszego Rektora, „Theologica Thoruniensia” 4 (2003) 13-27. 
wiązków zaczął jednak w pewnym momencie dawać o sobie znać - coraz częściej (jak pisze Ksiądz Profesor w swych wspomnieniach) zaczynała się pojawiać myśl o powrocie do Lublina. Ostatecznie po konsultacjach z Biskupem Ordynariuszem Toruńskim Andrzejem Suskim, Rektorem KUL ks. prof. Stanisławem Wielgusem oraz innymi osobami, pismem z dnia 9 maja 1997 r. skierowanym do ks. bp. Andrzeja Suskiego, ks. Franciszek Drączkowski prosił o przyjęcie jego rezygnacji ze stanowiska Rektora Wyższego Seminarium Duchownego Diecezji Toruńskiej, która została przyjęta przez Biskupa Ordynariusza 18 czerwca. Po 3 latach - w sierpniu 1997 r. - Ksiądz Profesor powrócił do Lublina. Jak zauważa w swej Autobiografii był to najpracowitszy okres w jego życiu - również pod względem dydaktycznym ${ }^{21}$.

Ksiądz Profesor swoją misję nauczycielską realizował (i nadal realizuje) nie tylko poprzez wykłady i seminaria naukowe, nie tylko przez wkład w wychowanie i formację kleryków w Lublinie, Pelplinie, Sandomierzu i Toruniu, ale także poprzez zwyczajne nauczanie wiernych podczas licznych rekolekcji (jedne z nich ukazały się w całości drukiem - wygłoszone w Sierakowicach w roku 2009) ${ }^{22}$, a przede wszystkim za pośrednictwem programów radiowych i telewizyjnych. Już bowiem w czasie rzymskich studiów miał kontakt z radiem, gdyż w okresie od 2 lutego 1975 do 7 marca 1976 r. wygłosił 14 homilii w języku polskim w Radiu Watykańskim, które później ukazały się drukiem ${ }^{23}$. Od wielu zaś lat Ksiądz Profesor dzieli się swoją wiedzą i przemyśleniami za pośrednictwem Radia Głos w Pelplinie, Telewizji Polskiej w Lublinie, ale przede wszystkim znany jest z programów na antenie Radia Maryja oraz Telewizji Trwam. Do chwili obecnej, przez 18 lat obecności na ich falach, Ksiądz Profesor wygłosił ponad 100 konferencji o charakterze pastoralno-formacyjnym oraz uczestniczył w ponad 20 programach telewizyjnych ${ }^{24}$.

Owocem wieloletniego prowadzenia wykładów z patrologii jest podręcznik dla studentów: Patrologia (Pelplin - Lublin 1998, 1999, 2001, 2009, 2012) liczący ponad 400 stron tekstu wraz z 11 mapami. Jest to, jak podkreślają recenzenci, najobszerniejszy z dotychczas napisanych podręczników patrologii $\mathrm{w}$ języku polskim, który w wielu ośrodkach akademickich stanowi podstawę do prowadzenia wykładów. Ważną pozycją na gruncie metodologii patrystycznej jest książka ABC pisania pracy magisterskiej (Pelplin 2000, 2009), która stanowi kompendium wiedzy dla magistrantów na temat metody naukowej stosowanej w badaniach patrystycznych.

${ }^{21}$ Por. tenże, Będę na wieki sławił łaski Pana, s. 156-157.

${ }^{22}$ Por. tenże, Rekolekcje w Sierakowicach, Pelplin 2009.

${ }^{23}$ Por. tenże, Do Boga, który uwesela.

${ }^{24}$ Zostały one zebrane w tomach: Piękno prawdziwe. Konferencje radiowe, Pelplin 1998; Pokój serca. Konferencje radiowe, Pelplin 1999; Błogosławieni znaczy szczęśliwi. Konferencje radiowe, Pelplin 2000; Niebo i piekło zaczyna się na ziemi. Radio „Maryja” Rozmowy niedokończone, Sandomierz 2002; Nasze powołanie do szczęścia, Pelplin 2005; Dzięki składajmy Panu Bogu naszemu. Zbiór konferencji wygloszonych w Radiu Maryja, Lublin 2006; Aby radość wasza byta petna. Konferencje radiowe, Pelplin 2012. 
Swoją działalność dydaktyczną w sposób oficjalny ks. prof. Franciszek Drączkowski zakończył z dniem 20 września 2013 r., kiedy to przeszedł na zasłużoną emeryturę.

W ramach swych obowiązków naukowych i dydaktycznych Ksiądz Profesor pełnił w minionych latach różne funkcje, które stanowiły styczną powyższych płaszczyzn jego życia. Był, lub wciąż jest: członkiem kolegium redakcyjnego półrocznika patrystycznego „Vox Patrum” - od 1981 r.; członkiem Komisji Rewizyjnej Towarzystwa Przyjaciół KUL - od 1985 do 1991 r.; przewodniczącym Wydziału Teologiczno-Kanonicznego Towarzystwa Naukowego KUL - od 1987 do 1990 r.; prodziekanem Wydziału Teologicznego KUL - od 1990 do 1993 r.; przewodniczącym Ogólnopolskiej Sekcji Patrystycznej przy Komisji ds. Nauki Katolickiej Konferencji Episkopatu Polski - od 1990 do $1996 \mathrm{r}$.

Pewną formą podsumowania mogą być nagrody i wyróżnienia, które ks. prof. Drączkowski otrzymywał za swoją posługę kapłańską oraz pracę naukową i dydaktyczną. W lutym 1988 r. ks. Franciszek Drączkowski został mianowany Kapelanem Honorowym Jego Świątobliwości Papieża Jana Pawła II, a w 1997 r. został mianowany przez Biskupa Toruńskiego Kanonikiem Honorowym Kapituły Katedralnej Toruńskiej. 28 października 1999 r. z rąk Rektora KUL ks. prof. Andrzeja Szostka otrzymał indywidualną nagrodę II stopnia za oryginalne i twórcze osiągnięcia naukowe oraz kształcenie kadr naukowych, zaś w sześć lat później - 21 grudnia 2005 r. - ks. prof. Stanisław Wilk, Rektor KUL, wręczył Księdzu Profesorowi nagrodę indywidualną I stopnia za przygotowanie i doskonalenie kadry naukowo-dydaktycznej oraz promowanie badań naukowych KUL w ośrodkach naukowych w Polsce i za granicą. 6 listopada 2006 r. ks. Drączkowski został odznaczony przez Prezydenta RP Lecha Kaczyńskiego Złotym Krzyżem Zastugi, zaś 21 lipca 2009 za szczególne zastugi dla oświaty $i$ wychowania Minister Edukacji Narodowej nadała mu Medal Komisji Edukacji Narodowej.

ks. Marcin Wysocki - Lublin, KUL 